\title{
Archetypal Orientations of Mind in Sociological Theory
}

\author{
Herman J Pietersen
}

\author{
Professor, University of Limpopo, Turfloop Campus, Sovenga, 0727
}

\section{Doi:10.5901/mjss.2014.v5n23p2190}

\section{Abstract}

A meta-theory was developed that brought together implicit premises or world views that constantly re-surface in human thought. Although these elements, which are often referred to as being the result of differences in human 'temperament', have long been part of the scholarly activity of humankind, a comprehensive synthesis has been lacking so far. In order to redress this shortcoming, an integrated perspective, supported by scholarly evidence, regarding basic characteristics of making sense of life and world was introduced. As a result, four paradigmatic or root intellectual orientations (designated as type I, type II, type III and type IV) have been identified. The theory was found to be applicable across a wide range of scholarly disciplines and cultures. In the present case the field of sociological theory is analyzed by using this framework. Four basic paradigms in the literature on sociological theory are identified and briefly described in terms of a survey of a few of examples of each metatype: the objectivist-empyrean, e.g., Comte, Parsons (type I sociology), the objectivist-empiricist, e.g., Durkheim, Merton (type II sociology), the subjectivist-empiricist, e.g., Mead, Goffman (type III sociology), and the subjectivist-empyrean, e.g., Marx, Critical Theory (type IV sociology). A separate section profiles the meta-orientations of Max Weber.

Keywords: Archetypal orientations, Durkheim, Parsons, Mead, Marx

\section{Introduction}

A meta-theory was developed that, in a coordinated manner, brought together axiomatic intellectual distinctions or world views that constantly re-surface in human thought.

The meta-theory was subsequently tested for its conceptual plausibility and evidentiary support across a wide range of scholarly disciplines, thinkers, topics and cultures. (Pietersen, 2011, 2014)

The present paper extends the application of the framework by showing that basic modalities of the mind also manifest themselves in the field of sociological theory. Figure 1 shows four orientations in human thought that are the result of a combination of two epistemological and two ontological stances, namely: objectivist-empyrean (type I); objectivist-empiricist (type II); subjectivist-empiricist (type III), and the subjectivist-empyrean (type IV). Figure 2 provides a description of characteristic elements of each of the basic modalities in human thought.

Figure 1: The four orientations in human thought

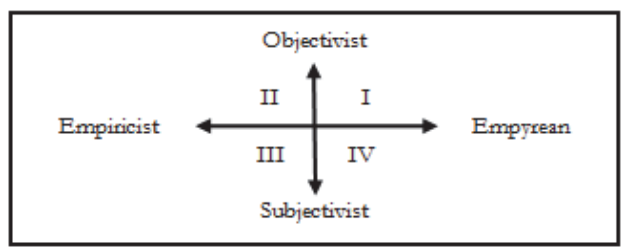

Figure 2: Characteristic elements of each of the basic modalities in human thought.

\begin{tabular}{|c|c|c|}
\hline \multicolumn{2}{|c|}{ Objectivist-Empiricist Orientation (type II) } & Objectivist-Empyrean Orientation (type I) \\
\hline$*$ & Emphasize reason (rationality) & * Emphasize reason (rationality) \\
\hline$*$ & Impersonal & * Impersonal \\
\hline 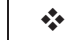 & Systematic-analytic & * Theoretical/integrative \\
\hline$\nLeftarrow$ & Microscopic focus & * Macroscopic focus \\
\hline$\star$ & Detailed explanation & * Comprehensive understanding \\
\hline$*$ & Concerned with verifiable ideas & * Concerned with possible ideas \\
\hline$*$ & To systematically analyze, order, predict and control & * To penetrate the deepest essentials and mysteries of \\
\hline
\end{tabular}




\begin{tabular}{|c|c|c|c|}
\hline \multicolumn{2}{|c|}{\begin{tabular}{|r|} 
life/world \\
\end{tabular}} & \multicolumn{2}{|c|}{ life/world. } \\
\hline \multicolumn{2}{|c|}{ Subjectivist-Empiricist Orientation (type III) } & \multicolumn{2}{|c|}{ Subjectivist-Empyrean Orientation (type IV) } \\
\hline$\%$ & Emphasize values (humanism) & $*$ & Emphasize values (humanism) \\
\hline$*$ & Personal-engaged & $\star$ & Communal-engaged \\
\hline$*$ & Experiential & $*$ & Conceptual \\
\hline 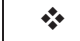 & Poetic-particular-critical & 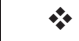 & Ideological-universal-reformist \\
\hline$*$ & 'Feeling with' (solidarity) & $\star$ & 'Feeling for' (development, becoming) \\
\hline$*$ & Concerned with individuals (the particularized other) & 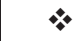 & Concerned with society (the generalized other) \\
\hline$\star$ & $\begin{array}{l}\text { To praise, eulogize, tell inspiring stories or To } \\
\text { unmask, debunk, criticize and tell 'sad' stories }\end{array}$ & 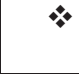 & $\begin{array}{l}\text { To change, renew and re-engineer life / world / } \\
\text { society according to valued ideals }\end{array}$ \\
\hline
\end{tabular}

Figure 3: Archetypal orientations in sociological theory

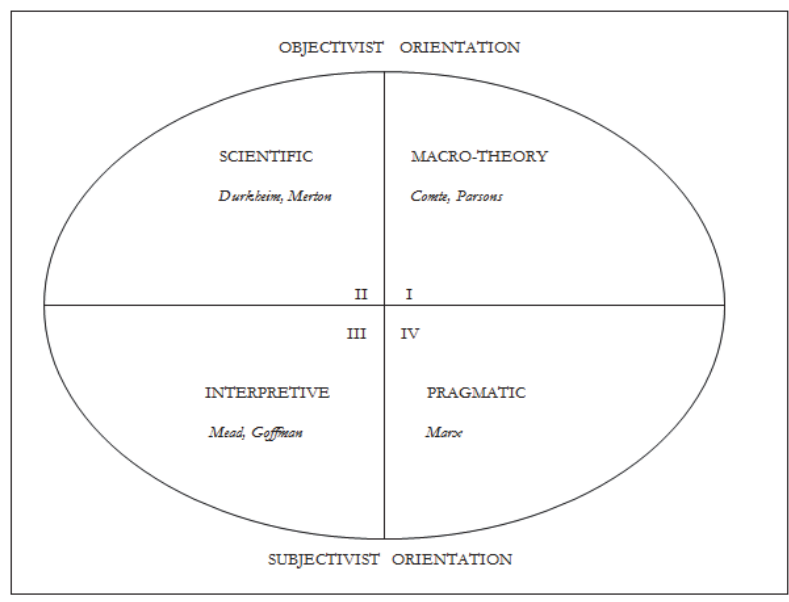

With the aid of the paradigmatic knowledge framework above, the literature on sociological theory is briefly examined with reference to a number of its major exemplars. The discussion that follows will neither focus in detail on particular theories or on sociologists, nor deal with a full-scale review of the relevant literature, as such. Instead, the focus will be on a broad conceptual analysis of the typical nature of thinking in this field. Toward this end reference may be made to Figures 1, 2 and 3.

\section{Brief Overview of Sociological Theory}

As sociologists know well, the discipline (and its name) had its origin in mid-nineteenth century France, with Auguste Comte's theory of 'positivism' which he proposed (and promoted) as a new science whose aim was to discover the 'laws' of society. Comte's ideas, which were still largely couched in metaphysical terms, were eventually taken up and extended by other leading thinkers such as Emile Durkheim, Max Weber, Georg Simmel, and Herbert Spencer, who desired to give shape to the new discipline as a science (as opposed to merely being a set of philosophical speculations): "Sociologists from the beginning were preoccupied with science, and many wanted to model sociology after the successful physical and biological sciences" (Ritzer, 1983: 8).

Strongly influenced by the negative socio-political fall-out and aftermath of the French Revolution of 1789, these writers were concerned about the resulting destructive effects on society, and wished to restore social order. To this day sociological thought is split between conservative (e.g., Durkheim, Weber) and radical (Marx, Marxian sociology) tendencies, the one faction preferring piece-meal or incremental social change, and the other (mainly Marxist) calling and organizing for revolutionary socio-political change. Thus, it is said, sociology has been from the 'beginning a highly political' intellectual endeavor (Ritzer, 1983: 41).

As Ritzer (1983) indicates, early European sociology (and much of mainstream $20^{\text {th }}$ century American sociological theorizing) focused on large-scale characteristics and elements of the social order regarded as a system of interdependent parts, dealing with aspects such as: "... roles, positions, relationships, structures, and institutions" (Ritzer, 1983: 10). In attempting to carve out a niche for itself sociological theorists in Europe regarded society as a more 
important unit of analysis than the individual. Much of the writing of these founders of the discipline was also an attempt to create a space for itself, especially between the fields of psychology on the one hand and anthropology on the other. American sociology followed a more liberal and individualist approach, as reflected in developments such as symbolic interactionism and ethnomethodology.

The sociological positivism of the conservative 1930s to 1950s (with Talcott Parsons as leading figure) was followed by greater attention to Marxian sociology and variants of symbolic interactionism (with its origins in Simmel, and especially the work of George Herbert Mead). Yet, as Smelser (1999) indicates: "Most sociologists engaged in research and teaching continue to perceive and believe that the world consists of empirical social facts and social problems, and they continue to describe, analyze, and explain these phenomena from a variety of sociological perspectives" (Smelser, 1999: 4).

His end of century review of American sociology points to some of the following trends:

- A concern with "...the relevance of sociological knowledge for social reform and revolution, [as well as] scientific vs humanistic sociology..." (Smelser, 1999: 3);

- In the 1960s and 1970s American sociology experienced the: "...vitalization of social behaviorism, symbolic interactionism, ethnomethodology, hermeneutics, and phenomenology generally" (Smelser, 1999: 4);

- The 1970s also witnessed the rise of: "...neo-Marxian, neo-Weberian, critical theory, and radicalsociology...taking as their targets the... functionalism, quietism, and conservatism of the 1950s" (Smelser, 1999: 4);

- The 1980s and 1990s reflected greater tolerance and a "...kind of peaceful pluralism... but also a sense of profound unease and loss of mission" (Smelser, 1999: 6).

\section{The Macro-Orientation in Sociological Theory (Type I: Objectivist-Empyrean)}

Before dealing with two main exemplars of the objectivist-empyrean orientation (namely, Comte and Parsons), it should be noted that there has been a series of developments in sociological theory in the 1970s and 1980s, concerned with a more integrated perspective on the discipline, of which the work of George Ritzer (1983) may be seen as a leading attempt to create a meta-sociological framework.

Briefly, Ritzer (1983) identifies three sociological paradigms (the social factist, social definitionist and social behaviorist) and four levels of reality (the macro-objective, macro-subjective, micro-objective and micro-subjective).

Taking his lead from the philosophy of science of Thomas Kuhn, his aim is to provide: "...a meta-sociological schema that allows us to analyze sociological theory in a coherent fashion" (Ritzer, 1983: 312). It should be pointed that this scheme or model (not yet a full-blown theory as such) reflects a development internal to sociology, and is mainly embedded in the type II (scientific) general orientation in human thought. In terms of the meta-theory utilized in the current paper, it is clear that Ritzer's main focus is on a social ontology (different levels of reality) of different scope (micro to macro). Thus, he does not directly deal with the epistemological and pragmatic (advocacy) dimensions or orientations of mind (see Pietersen, 2011 for an exposition).

The following sections briefly describe some of Auguste Comte's and Talcott Parson's ideas as evidence of the objectivist-empyrean (type I) tendency in sociological theory.

\subsection{Auguste Comte}

Although he wished for the new discipline of sociology to develop into a science of social laws, his writing (as mentioned before) was still largely expressed in philosophical terms.

However, Comte did express the need for empirical research (type II activity), yet his own work remained at an abstract level.

The following brief extracts show his type I orientation:

- His theory is concerned with both: "...social statics (existing social structures) and social dynamics (social change)" (Ritzer, 1983: 12);

- He postulates three stages in intellectual history, namely, the theological (God is everything), the metaphysical (nature is everything) and positivistic (natural and human science) (Ritzer, 1983: 12);

- He believes that only when positivism gains control will societal upheavals cease, there is no need for revolutionary change (Ritzer, 1983: 13);

- He emphasizes the: "...systematic character of society and the links among and between the various 
components of society..." (Ritzer, 1983: 13).

\subsection{Talcott Parsons}

In the American context Talcott Parsons is the major exemplar of a comprehensive sociological theory in the objectivistempyrean tradition of thought. His encompassing theory of society as a social system is: "... probably the most elaborate formulation that has been produced to date within the functionalist framework" (Walsh, 1972: 58), although it should be said that his theory is criticized for lacking a satisfactory explanation of: "...how actors come to recognize roles and perform them accordingly" (Walsh, 1972: 64).

Parsons writes about the aim and nature of his structural-functional approach in the following manner:

- It is: "... an attempt to bring together, in systematic and generalized form, the main outlines of a conceptual scheme for the analysis of the structure and processes of social systems" (Parsons, 1951: vii);

- It is: "...not an attempt to formulate a theory of any particular concrete phenomenon, but...the attempt to present a logically articulated conceptual scheme" (Parsons, 1951: 536).

Ritzer (1983) adds the following meta-theoretically relevant aspects of the work of Parsons, namely, that:

- " "...t served to introduce grand-style European theorizing to a large American audience..." (Ritzer, 1983: 51);

- His view of intra-systemic and inter-systemic relations in society was that: "...they were defined by cohesion, consensus, and order. In other words, the various social structures performed a variety of positive functions for each other" (Ritzer, 1983: 52);

- In Parsons functionalism the: "...higher-order systems control the lower-order ones; the lower-order systems provide the conditions, or the energy, needed by the higher-order systems to exist [and] although he did have much to say about the personality system, he thought of personality as controlled by larger-scale systems" (Ritzer, 1983: 75);

- He focuses more on the 'status-role complex' in his system, in which the social actor is seen as: "...nothing more than a bundle of statuses and roles" (Ritzer, 1983: 78);

- According to Parson's scheme a social system must have four functions in order to survive, namely: adaptation, goal attainment, integration and pattern maintenance (Ritzer, 1983: 79).

\section{The Scientific Orientation in Sociological Theory (Type II: Objectivist-Empiricist)}

\subsection{Emile Durkheim}

Emile Durkheim is the most scientifically-oriented of the founders of sociology, essentially responding to Comte's earlier call for empirical research. Given his emphasis on social facts (especially of sociological phenomena as immaterial 'social' facts) he has subsequently been described as the primary exemplar of social factism in the discipline.

The following brief extracts from his best known work, The Rules of Sociological Method (1966/1938), clearly shows his aim of making sociology a respectable science, worthy of being in the company of other sciences:

- "...our principal objective is to extend scientific rationalism to human behavior" (Durkheim, 1966: xxxix);

- "Sociology can then be defined as the science of institutions, of their genesis and of their functioning" (Durkheim, 1966: Ivi);

- "The first and most fundamental rule is: Consider social facts as things" (Durkheim, 1966: 14);

- "A social fact is every way of acting, fixed or not, capable of exercising on the individual an external, constraint; or again, every way of acting which is general, throughout a given society, while at the same time existing in its own right independent of its individual manifestations" (Durkheim, 1966: 13);

- "We must, therefore, consider social phenomena in themselves as distinct from the consciously formed representations of them in the mind; we must study them objectively as external things, for it is this character that they present to us" (Durkheim, 1966: 28);

- "When, then, the explanation of a social phenomenon is undertaken, we must seek separately the efficient cause which produces it and the function it fulfils" (Durkheim, 1966: 95);

- "The principal task of the sociologist ought to be, therefore, to discover the different aspects of this milieu which can exert some influence on the course of social phenomena. Until the present, we have found two series of facts which have eminently fulfilled this condition; these are: (1) the number of social units or, as we have also called it, the 'size of a society' and (2) the degree of concentration of the group, or what we have 
termed the 'dynamic density"' (Durkheim, 1966: 113);

- "To sum up, the distinctive characteristics of our method are as follows: First, it is entirely independent of philosophy. ... All that it asks is that the principle of causality be applied to social phenomena" (Durkheim, 1966: 141);

- Typical of those with a strong scientific (type II) approach to the world, Durkheim clearly shows his antipathy toward type IV (social change) theorizing, when he states that: "On principle, it will ignore these theories, in which it could not recognize any scientific value, since they tend not to describe or interpret, but to reform, social organization" (Durkheim, 1966: 142).

\subsection{Robert Merton}

Merton became a leading figure in mid to late twentieth century functionalist sociology with his joint emphasis on giving greater specificity to functionalist concepts, and on the need for empirical research. His Type II (objectivist-empiricist) orientation is evidenced in the following brief extracts:

- Referring to an earlier paper of his on Durkheim, Merton expresses his approval of: "...at least one methodological and procedural expression of positivism: the systematic use of empirical indices of conceptualized 'social facts' which are not directly observable" (Merton, 1994: 34);

- He goes on to state that: "I have since continued to cite Durkheim, and to expatiate relentlessly, on the methodological importance of couching sociological and social thought in terms of concepts and their empirically observable manifestations" (Merton, 1994: 35).

Ritzer (1983) adds the following comments on Merton's approach:

- "Merton's essay, "Toward the Codification of Functional Analysis in Sociology" is the most important statement on structural functionalism in sociology" (Ritzer, 1983: 88);

- "Merton's position was that all of these [Parsonian] functional postulates rely on non-empirical assertions based on abstract, theoretical systems. At a minimum, it is the responsibility of the sociologist to examine each empirically, [hence] his belief that empirical tests, not theoretical assertions, are crucial to functional analysis" (Ritzer, 1983: 89).

\section{The Interpretive Orientation in Sociological Theory (Type III: Subjectivist-Empiricist)}

There are various theoretical approaches in the subjectivist-empiricist (or so-called micro-sociological) tradition, only a few of which will briefly be treated in this section.

\subsection{Georg Simmel}

At the root of mostly North-American schools of sociological thought is the pioneering work of Georg Simmel (a contemporary of Max Weber), who emphasized smaller-scale issues such as the individual and individual interaction (see Wolff, 1950; Ritzer, 1983), though he also made substantial contributions to the large-scale sociology of structuralfunctionalism in Germany. His work became a main influence on the Chicago school of symbolic interactionism (with George Herbert Mead as leading figure).

Simmel expresses his approach (which is clearly different from mainstream functionalism) as follows:

- "The large systems and the super-individual organizations that customarily come to mind when we think of society, are nothing but immediate interactions that occur among men constantly... To be true to this fundamental character of it, one should properly speak, not of society, but of sociation. Society merely is the name for a number of individuals, connected by interaction" (Wolff, 1950: 11);

- According to Ritzer (1983): "...Simmel saw that understanding interaction among people was one of the major tasks of sociology...[and] he also wrote a set of deceptively simple essays on such interesting topics as poverty, the prostitute, the miser and the spendthrift, and the stranger..." (Ritzer, 1983: 29).

\subsection{Symbolic Interactionism}

In their noteworthy Symbolic interactionism: Genesis, varieties and criticism, (1975) Meltzer, Petras and Reynolds identify the following characteristics or basic premises of this approach in sociological theory, namely: 
- "The influence that stimuli have upon human behavior is shaped by the context of symbolic meanings within which human behavior occurs. These meanings emerge from the shared interaction of individuals in human society: (Meltzer et al, 1975: vii);

- "First, human beings act towards things on the basis of the meanings that the things have for them. Secondly, these meanings are a product of social interaction in human society. Thirdly, these meanings are modified and handled through an interpretive process that is used by each individual in dealing with the things he/she encounters" (Meltzer et al, 1975: 1).

\subsection{George Herbert Mead}

Mead is an interesting figure in that he was a combination of pragmatist philosopher and social behaviorist who placed a strong emphasis on experience and on the dialectical relationship within the Self, of the free, acting individual (the "I") and his/her internalized social other, namely, the attitudes, norms, and values of society (the "Me").

Some key elements of his approach, as he explains it, are as follows:

- "The point of approach which I wish to suggest is that of dealing with experience from the standpoint of society, at least from the standpoint of communication as essential to the social order" (Mead, 1962/1934: 1);

- "Meaning appears within that process. Our behaviorism is a social behaviorism" (Mead, 1962/1934, 6);

- "The individual experiences himself as such, not directly, but only indirectly, from the particular standpoints of other individual members of the same social group, or from the generalized standpoint of the social group as a whole to which belongs" (Mead, 1962/1934, 138);

- "The self, as that which can be an object to itself, is essentially a social structure, and it arises in social experience" (Mead, 1962/1934, 140);

- "The organized community or social group which gives to the individual his unity of self may be called the "generalized other. The attitude of the generalized other is the attitude of the whole community" (Mead, 1962/1934, 154).

\subsection{Erving Goffman}

Goffman's influential work in the subjectivist (type III) tradition of micro-sociological theory is entitled: The Presentation of Self in Everyday Life (1959), which he describes as follows:

- "The perspective employed in this report is that of the theatrical performance: the principles derived are dramaturgical ones. I shall consider the way in which the individual in ordinary work situations presents himself and his activity to others, the ways in which he guides and controls the impression they form of him, and the kinds of things he may and may not do while sustaining his performance before them" (Goffman, 1959: 9);

- "...I assume that when an individual appears before others he will have many motives for trying to control the impression they receive of the situation. This report is concerned with some of the common techniques that persons employ to sustain such impressions and with some of the common contingencies associated with the employment of these techniques" (Goffman, 1959: 26);

- "It is concerned with the structure of social encounters - the structure of those entities in social life that come into being whenever persons enter one another's immediate physical presence. The key factor in this structure is the maintenance of a single definition of the situation, this definition having to be expressed, and this expression sustained in the face of a multitude of potential disruptions" (Goffman, 1959: 246).

\section{The Pragmatic Orientation in Sociological Theory (Type IV: Subjectivist-Empyrean)}

Although the work of Karl Marx, who was not (and did not consider himself to be) a sociologist, is commonly associated with revolutionary social change, also in sociological theory, the other founding figures such as Comte, Durkheim and Weber were also attempting to influence the social order in the pragmatic (political) orientation of the type IV tradition of human thought (see Koppel, 2008). However, their concern was with incremental social engineering in the conservative political tradition, rejecting (if not abhorring) an ideology of radical change.

In sociology, various forms of Marxian theory exist. However, in the present paper and for purposes of showing the existence of the type IV (subjectivist-empyrean) orientation in sociological theory, only some of the ideas of Marx will briefly be noted. 


\subsection{Karl Marx}

For Marx it was more important to change history than understanding it. As he famously stated: "...Philosophers have only given different interpretations of the world; the important thing is to make it different." (Taylor, 1967: 27)

Some elements of Marx's reformist ideology (see Marx \& Engels, 1848; Marx, 1844) are as follows:

- The history of all hitherto existing society is the history of class struggles;

- The existence of classes is only bound up with particular, historic phases in the development of production;

- Society as a whole is more and more splitting up into two great hostile camps, into two great classes directly facing each other: Bourgeoisie and Proletariat;

- The class struggle necessarily leads to the dictatorship of the proletariat;

In an interview with him in 1871, Marx re-iterated the basic aim of the Communist movement, namely "...The economical emancipation of the working class by the conquest of political power [and] the use of that political power to the attainment of social ends. It is necessary that our aims should be thus comprehensive to include every form of working-class activity...and...that means they must transform society." (Landor, 1871: 5).

\section{The Meta-Theoretical All-Rounder: Max Weber}

The reason for a separate section on one of the giants of sociology, Max Weber, is simply that within the context of the current meta-theoretical discussion, his work is, to greater or lesser extent, a manifestation of all four basic orientations of mind.

This may at least partly explain the fact that throughout the past century his work (although highly influential) also seemed to have generated mixed reaction and criticism among sociologists of various persuasions. Udehn (1981), for instance, points to the conflict between Weber's interpretive methodology of verstehen and his rationalist sociology of bureaucratic institutions. Eliaeson (2000), in his discussion of different conceptualizations of Weber's methodology, observes that: "The result was a fractured image of Weber as simultaneously a positivist and an anti-positivist... He has been represented as a macro-theoretical functionalist [by Parsons], a founding father of empathetic interpretative sociology (Verstehen), even a phenomenologist [by Schutz], as well as an empirical-survey pioneer [by Lazarsfeld]" (Eliaeson, 2000: 241).

In The Protestant Ethic and the Spirit of Capitalism (1985/1904), Weber emphasizes in typical positivist (type II) fashion that: "It must be one of the tasks of sociological and historical investigation first to analyze all the influences and causal relationships which can satisfactorily be explained in terms of reactions to environmental conditions" (Weber, 1985: 31).

A major text on Weber, by Gerth and Wright-Mills (1946), offers the following observations, which again shows the conflicting nature of Weber's thought (meta-theoretically-speaking):

- 'In his writings on method, Weber rejects the assumption of any 'objective meaning.' He wished to restrict the understanding and interpretation of meaning to the subjective intentions of the actor" (Gerth and Wright-Mills, 1946: 58);

- "His attachment to Western positivist thought is shown in his scorn for any 'philosophical' or 'metaphysical' elements in the social sciences. He wants to give these sciences the same matter-of-fact approach with which the natural sciences approach nature" (Gerth and Wright-Mills, 1946: 59).

In conclusion, Max Weber's work stretches more widely across all four basic modalities of mind, although his emphasis on rationalization, his evidence-based conceptualizations, and his various typologies seem to nudge him toward the objectivist modes of thought.

He was clearly a multi-faceted sociologist (perhaps more so than any of the other early figures, such as Comte and Durkheim), namely: the typologist (i.e., theorist of bureaucratic types - type I); the scientist, using evidence from comparative /historical studies of religions across occupations and advocating the use of questionnaires in sociological research - type II); the interpretive sociologist of verstehen (type III); as well as being active in German politics and creating a sociological society (type IV).

\section{Concluding Remarks}

A meta-theory that was previously developed brought together implicit premises or world views that constantly re-surface in human thought. Subsequently, four paradigmatic or root intellectual orientations (designated as type I, type II, type III 
and type IV) have been identified.

The theory was found to be applicable across a wide range of thinkers, scholarly disciplines, and cultures. In the present paper the field of sociological theory is discussed in terms of a brief survey of various examples of each metatype: the macro-theoretical (type I); the positivist (type II); the narrative-interpretive (type III), and the pragmatic (type IV).

\section{References}

Durkheim, E (1966/1938) The Rules of Sociological Method, Eighth edition, Translated by Sarah A. Solovay and John H. Mueller and edited by George E.G. Catlin; New York: The Free Press.

Eliaeson, S (2000) Max Weber's methodology: An ideal-type, Journal of the History of the Behavioral Sciences, Vol. 36(3), 241-263

Gerth, H. H. and C. Wright Mills (1946) From Weber: Essays in sociology, New York: Oxford University Press.

Goffman, E. (1959) The Presentation of Self in Everyday Life, England: Penguin Books

Koppel, R. (2008) The utility of sociology, Sociological Viewpoints, Vol. 5, p6 - 16

Landor, R. (1871) 'Interview with Karl Marx, Head of L'Internationale revolt of labor against capital - The two faces of L'Internationale transformation of society - its progress in the United States', New York World, July 18, 1871; reprinted Woodhull \& Claflin's Weekly, August 12, 1871 , London, July 3, p5

Marx, K. (1888) Ludwig Feuerbach and the End of Classical German Philosophy. Marx \& Engels Internet Archive (www.marxists.org), 2001, p30.

Marx, K. and F. Engels (1848) The Communist Manifesto. Translated by R J Hollingdale, Introduction by A. J. P. Taylor. 1967. England: Penguin

Mead, G. H. (1962 /1934) Mind, Self, and Society from the standpoint of a social behaviorist, (Edited with introduction by Charles W. Morris), Chicago: University of Chicago Press.

Meltzer, B.N.; Petras, J.W.; Reynolds, L.T. (1975) Symbolic interactionism: Genesis, varieties and criticism, Boston. Massachusetts: Routledge \& Kegan Paul

Merton, R. K. (1994) Durkheim's 'Division of Labor in Society': A sexagenarian postscript, Sociological Forum, Vol. 9, No. 1, 1994, pp 27 $-37$

Parsons, T (1951) The Social System, Glencoe, Illinois: The Free Press

Pietersen, H. J. (2011) The Four Types of Knowing - Metaphysical, Scientific, Narrative and Pragmatic: A Meta-Epistemology of Mind, New York: Edwin Mellen Press.

Pietersen, H. J. (2014) The Four Archetypal Orientations of the Mind: Foundational, Experiential, Organizational and Actional, New York: Edwin Mellen Press.

Ritzer, G. (1983) Contemporary Sociological Theory, New York: Alfred A. Knopf.

Smelser, N. J. (1999) Looking back at 25 years of sociology and the Annual Review of Sociology, Annual Review of Sociology. Vol. 25:1 $-18$

Taylor A. J. P. (1967) 'Introduction', in K. Marx and F. Engels. 1848. The Communist Manifesto. Translated by R.J. Hollingdale, England: Penguin, p27

Udehn, I (1981) The conflict between methodology and rationalization in the work of Max Weber, Acta Sociologica, Vol. 24, 3, p131 147.

Walsh, D (1972) Functionalism and Systems Theory. In: Filmer, P; Phillipson, M; Silverman, D \& D. Walsh (1972), New Directions in Sociological Theory. London: Collier-Macmillan

Weber, M (1985/1904-5) The Protestant Ethic and the Spirit of Capitalism, London: George Allen and Unwin.

Wolff, K. H. (1950) The Sociology of Georg Simmel, Glencoe, Illinois: The Free Press. 